\title{
Linguistic Theory in the Practical Lexicography of the African Languages
}

\author{
Emmanuel Chabata, African Languages Research Institute, University of \\ Zimbabwe, Harare, Zimbabwe; and Siswati National Lexicography Unit, \\ Tshwane University of Technology, Nelspruit Campus, Nelspruit, Republic of \\ South Africa (echabata@arts.uz.ac.zw)
}

\begin{abstract}
In this article, we look at the relationship between linguistics and lexicography. We specifically look at the relevance of data derived from theoretical linguistic investigations to the compilation of dictionaries in African languages. Our point of departure is that since it is language description that lies at the core of both lexicography and linguistic theory, lexicographers can improve their work by using insights from theoretically-guided linguistic investigations. Our view is that as long as lexicographers focus on words and their existence in the linguistic system, they cannot work effectively without referring to linguistic theory, consciously or unconsciously. Lexicography is not only concerned with dictionary creation, that is, with the collection of lexical units and their proper description in dictionary entries, but also with the theoretical aspects concerning the lexicon. It is necessary for dictionaries to capture all lexical interrelationships of a phonetic, morphological, syntactic or semantic nature. Drawing examples from a few dictionaries on African languages, we try to show how dictionary compilers have benefited from specific theoretical investigations in general linguistics. We look at how the different linguistic theories have contributed to the improvement in the quality of the contents of some dictionaries of African languages. Our conclusion is that there is a stronger bond between linguistic theory and lexicographic practice than is generally assumed. Ways must therefore be found to understand the various links between the two disciplines. There should be a deliberate move from mutual neglect to collaboration between the two disciplines.
\end{abstract}

Keywords: AFRICAN LANGUAGES, DICTIONARY, GRAMMATICAL CATEGORISATION, HEADWORD SELECTION, LEXICAL MEANING, LEXICOGRAPHER, LEXICOGRAPHY, LINGUIST, LINGUISTICS, LINGUISTIC THEORY, PRACTICAL LEXICOGRAPHY, TONE MARKING

Opsomming: Linguistiese teorie in die praktiese leksikografie van die Afrikatale. In hierdie artikel kyk ons na die verhouding tussen die linguistiek en die leksikografie. Ons kyk veral na die tersaaklikheid van gegewens ontleen aan teoretiese linguistiese ondersoeke vir die samestelling van woordeboeke in die Afrikatale. Ons uitgangspunt is dat, aangesien dit taalbeskrywing is wat die kern van sowel die leksikografie as die linguistiese teorie vorm, leksikograwe hulle werk kan verbeter deur die insigte van teoreties-geleide linguistiese ondersoeke te gebruik. Ons siening is dat solank leksikograwe op woorde en hul bestaan in die linguistiese stelsel fokus, hulle nie doeltreffend kan werk sonder om bewustelik of onbewustelik na linguistiese teorie 
te verwys nie. Dit is noodsaaklik vir woordeboeke om alle onderlinge leksikale verhoudinge van 'n fonetiese, morfologiese, sintaktiese en semantiese aard te ondervang. Deur voorbeelde uit 'n paar woordeboeke van Afrikatale te neem, probeer ons toon hoe woordeboeksamestellers voordeel getrek het uit spesifieke teoretiese ondersoeke in die algemene linguistiek. Ons kyk hoe die verskillende linguistiese teorieë bygedra het tot die verbetering van die gehalte van die inhoud van sommige woordeboeke van Afrikatale. Ons gevolgtrekking is dat daar 'n sterker verband tussen linguistiese teorie en leksikografiese praktyk is as wat algemeen aanvaar word. Maniere moet daarom gevind word om die verskillende skakels tussen die twee dissiplines te verstaan. Daar behoort ' $n$ doelbewuste beweging te wees van wedersydse verwaarlosing tot samewerking tussen die twee dissiplines.

Sleutelwoorde: AFRIKATALE, GRAMMATIESE KATEGORISERING, LEKSIKALE BETEKENIS, LEKSIKOGRAAF, LEKSIKOGRAFIE, LINGUIS, LINGUISTIEK, LINGUISTIESE TEORIE, PRAKTIESE TEORIE, TOONMARKERING, TREFWOORDKEUSE, WOORDEBOEK

\section{Introduction}

The debate on the relationship between lexicography and linguistics, or more specifically, on the relevance or usefulness of theory-based linguistic descriptions to dictionary making, is not new. In fact, the debate could be as old as the establishment of lexicography as a discipline. On the one hand, there is scholarship in favour of the separation of theoretical linguistics and lexicography. This scholarship does not recognise lexicography as a branch of linguistics. Because of this, the view is that there should be no link between theoretical linguistics and dictionary making. The linguists in this category considered lexicographers as non-linguists. In linguistic circles, dictionaries were therefore regarded as lacking linguistic interest since they were said to be produced without the help of any linguistic theory. The dictionary was seen as too unscientific to be worthy of any serious academic interest. It may be because of such scholarship that lexicography has sometimes even been referred to as an art (see, for example, Landau 2001), and sometimes as a descriptive venture that should avoid any link with theory whatsoever (see, for example, Geeraerts 1987). In defence of their field of study, lexicographers did not see the relevance of linguistic research in the compilation of dictionaries. They did not recognise how theoretical linguists could contribute to the practical work of dictionary making. As noted by Béjoint (2000: 170), practical lexicographers felt that academics would be of little use in lexicographic work with all its practical and social constraints to which linguistic theory was said to be ill-adapted. The same is also echoed in Urdang (1963: 594) who warns that although more theoreticians will be a welcome addition to the field of lexicography, they must remember that their theories should be interpretable above all in terms of practicality.

It is during the second half of the twentieth century that the interest of linguists in lexicography began to be noticed. Lexicographers also started to see 
linguistic theory as an important tool that they could use in improving their dictionaries. The new philosophy on both sides was that the two fields are interrelated, making it possible to successfully contribute to and supplement each other. This scholarship was concretised by the publication of Zgusta's 1971 Manual of Lexicography, which heralded a new approach towards lexicography, linking lexicography to linguistic theories (and we should note in passing that this work of Zgusta has had much influence on African lexicography). By devoting a great deal of space to issues not primarily concerned with lexicography but rather with linguistics and linguistic theory (for example, focusing on topics such as lexical meaning, formal variation of words, and combinations of words), Zgusta gives a clear indication that linguistic influence does not only, or even primarily, run along the lines of formal grammar but that the dictionary needs to reflect real language usage and not only the language of the ideal speaker-hearer (Gouws and Prinsloo 2005: 2). Given the then scepticism prevalent among some linguists regarding the position of lexicography as a sub-domain of linguistics, Zgusta's work signals that a sound lexicographic practice utilises a sound linguistic analysis. Thus, since 1971, varying degrees of proximity have prevailed between lexicography and linguistics with different theories in linguistics having a bigger or lesser influence on lexicographic practice. Commenting on the current relationship between the two fields, Béjoint (1994: 177) notes that "lexicography and linguistics are now inextricably mixed" because precision and quality of work in lexicography often has to rely on evidence provided by linguistics. He (Béjoint 1994: 172) observes that, to date, the relations between linguists and lexicographers are strong, going in both directions. To illustrate his observation, Béjoint (2000) notes that linguists such as David Crystal and John Sinclair are involved in the compilation of dictionaries and lexicographers like Patrick Hanks are also linguists. Similarly, Hartmann (1983: 4) argues that in order to compile a dictionary, one must have a notion of the "word" and an understanding of how words are used in interpersonal discourse. He (Hartmann 1983: 4) further argues that the discipline that has contributed most to an understanding of the use of words in communication is linguistics, that is, much of the literature on lexicography has consciously and explicitly related itself to linguistic theories in general and to theories of lexical semantics in particular.

In this article, we try to show how lexicographers seek the intervention of linguistic theory in many aspects of their work. We argue that dictionary compilers consciously or unconsciously depend on previous linguistic studies, for example, when deciding on what kinds of semantic information to present in a dictionary (see Hartmann 1983 and Svensén 1993 among others). Our position is that lexicography could be made more systematic, consistent and comprehensive with the help of a rigorous use of data derived from theoretical linguistic analyses. In line with this, we propose a stronger theoretical linguistic basis to enhance the linguistic authority of dictionaries. In fact, we will note that, knowingly or unknowingly, lexicographers in some African languages 
http://lexikos.journals.ac.za

have been influenced to a great extent by insights derived from linguistic theory. This observation is supported by the fact that most of the current lexicographers working with African languages are linguists by training, and that they are even attached to departments of linguistics or African languages at different African universities. Because of this, we believe that linguistic theory has provided part of the much needed training for doing good lexicographic work. We therefore agree with Yong and Peng (2007: 41) who argue that the link between lexicography and theoretical linguistics explains why both practical and theoretical lexicography have undergone significant advances in the past three decades, a period during which there was a marked development in theoretical linguistics.

Our belief is also that a theory, in general, both serves as a guide to discovery and as a tool bringing insights in a revealing way. It helps us to deal with both the known and the unknown. It is in this light that Hyman (2006: 13) argues that with linguistic theories, we obtain a better description and understanding of language issues in question. He (Hyman 2006: 13) further holds the opinion that linguistic theories might lead researchers to ask questions they may not otherwise have raised about language structure and to seek data they may not otherwise have considered. In addition, theoretical awareness helps researchers see connections that might otherwise not be made, as well as pinpointing problems that might have been overlooked. Experience in compiling dictionaries in African languages has shown that by using data from theoretically guided investigations into linguistic structure, lexicographers increase their chances of producing a more accurate and comprehensive language description. It is actually because of the great influence that theoretical investigations into linguistic structure have had on African lexicography that Gouws and Prinsloo (2005: 2) conclude that the advent of modern lexicography is positioned within the broader framework of linguistics. It is also because of this that they go a step further and propose that lexicographers should always take cognisance of developments in linguistic theory and that data presented in dictionaries should result from a sound linguistic analysis.

For us to appreciate the importance or relevance of data derived from theoretical linguistics for lexicography, we have to accept that language is at the centre of both theoretical linguistics and lexicography. Good (1988: 81) notes that both practical dictionary writers and linguists are involved, strictly speaking, in the same task: that of providing a description of the lexical stock of a language, or alternatively, of modelling the linguistic knowledge of native speakers. For example, in lexicography the most common tasks include the provision of meaning as well as the description of grammatical behaviour and pronunciation of words, their stylistic characteristics and other aspects of their usage, all of which are at the core of the development and application of linguistic theories. In both disciplines and/or practices, the goal is to describe language. The only difference may be that whilst in theoretical linguistics each theoretical approach is a description of language from some narrow and spe- 
cific perspective, in practical lexicography the goal is to try and describe a language or languages in their totality - the aim in practical lexicography being to fully describe linguistic concepts. If this assumption is accepted, therefore, we would proceed to argue that it is only data from various perspectives or theoretical investigations that can or should be corroborated to help in the provision of the much needed basis for fuller descriptions of lexical items in dictionaries. The processes of compiling, editing and extending dictionaries as well as research on dictionaries should thus profit from progress and developments in linguistics and its various branches, that is, among others, sociolinguistics, psycholinguistics, pragmatics and semantics. We have already argued above that since lexicographers specifically deal with words, they should rely on advances in linguistic theory for understanding what a word is before they can be able to provide words with definitions, pronunciation and other details. They should, for example, have a fuller understanding of whether a word is a sequence of sounds (that is, a phonological word), a sequence of letters (a graphic word), a formal unit composed of several components (a morphological word) or a unit expressing meaning (semantic word). Given the interdisciplinary nature of dictionaries, lexicographers should not only follow developments in linguistic theory but should also benefit from many other fields such as terminology, information technology, language teaching, translation, psychology, philosophy, history and science.

However, whilst we acknowledge the importance of linguistic theory for dictionary compilation, we should not forget that lexicographers are doing scientific work but publishing it for users whose pursuits are always more practical, and who are usually not trained linguists or lexicographers. In the light of this, therefore, practical lexicographers should negotiate their way well between linguistic data derived from serious linguistic theories and the parallel needs of dictionary users. In a way, our considered position is that although linguistic theories are useful to practical lexicography by providing relevant and precise data about linguistic concepts, lexicographers should not be obsessed with linguistic theories; that is the field for linguists. Instead, these theories should only be used to enhance the efforts of practical lexicographers in their task of dictionary making, a task with its own specific needs and goals. Lexicographers should not be led by the demands of different linguistic theories to the extent that the principles or goals of lexicography as a discipline are compromised. For example, they should not fail lexicographic user-perspective ideals such as user-friendliness and historical and cultural sensibilities of the target audience. The reason for this is aptly captured by Gouws and Prinsloo (2005) who describe a dictionary as "the display-window of linguistics". They note that the people who look at these display-windows are not trained linguists but rather average members of the relevant speech community. Similarly, Zgusta (1971) argues that lexicographers need to be familiar with linguistics in a much broader sense, taking into consideration not only the whole structure of the language in question but also the culture of the respective lin- 
guistic community. Thus, our position is that lexicographers should not aim at producing linguistically sophisticated products, but that their linguistic sophistication should help them produce informative and useful products for their intended users.

Having declared our position regarding the importance of data derived from theory-based linguistic investigations as well as other lexicographic aspects to which lexicographers have to pay attention, we will try to show how some linguistic theories might be taken into account to the benefit of lexicographic practice. In our presentation, we will consider different parts of a typical monolingual dictionary entry, and then try to show how the treatment of the respective parts has benefited from a relevant linguistic theory or theories. To appreciate the different aspects on which we will focus, let us consider the way some lexicographic data has been presented in the following dictionary entry from Chimhundu (1996), a general monolingual Shona dictionary.

muswe [musve] DK z 3. 1 Muswe inhengo yemuviri wemhuka inomera kumagumo emusana, kana kurembera, inopinimidza kumashure. (A tail is a part of an animal's body found hanging at the end of its back.) FAN muchira 3. 2 Muswe munhu anosaririra shure pakuita zvinhu. (Muswe is a person who lags behind in doing something.)

In this example, the word given in bold, muswe (tail), is the headword, that is, the word being described, and in square brackets is shown its variant form. Following this variant, the letters $\mathrm{D}$ and $\mathrm{K}$ represent tone marking. Whilst $\mathrm{D}$ is an abbreviation for -dzikisa (low tone), $\mathrm{K}$ is an abbreviation for -kwidza (high tone). Thus, muswe is pronounced as low, high. On the tone marking follows the abbreviation $z$, the short form for zita (noun) indicating that muswe belongs to the grammatical category of nouns. This is also followed by a number 3 , which shows the class to which the noun belongs in the Shona noun class system. If it is a verb, for example, tone marking would be followed by abbreviations indicating whether the verb is transitive or intransitive. After the information on grammatical categorisation, the two meanings of the word numbered as $\mathbf{1}$ and $\mathbf{2}$ follow. At the end of meaning 1, FAN muchira 3 is found, where FAN is an abbreviation for fanana, loosely meaning "same as", and implying that muchira is synonymous with muswe and also belongs to class 3 .

Now, also drawing our examples mainly from Shona, we will try to show how the lexicographer makes his/her decisions on each of these aspects, and how linguistic theory can help in the decision-making process. Aspects that will be focused on are headword selection, tone marking, grammatical categorisation and meaning.

\section{Headword selection}

It has become common knowledge in lexicographic practice that a dictionary cannot contain all the words and phrases of a language, no matter its size or 
scope. Because of this, headword selection forms an important stage in the compilation of any dictionary, for it determines the major contents of a particular dictionary. As noted by Landau (1984: 185), the decision to include or exclude a particular category of words relates directly to the purpose of the dictionary. Whatever the lexicographer eventually includes in or omits from the dictionary, must be the result of convincing reasons; the selection principles should be well-considered. The important question then is, "What are the lexicographer's selection criteria and where does linguistic theory come in?" To illustrate lexicographers' usual dilemma, let us consider the following sets of Shona derivations.

(2) (a) -famba (walk) vs mufambi ((some)one who is walking)

(b) -tenga (buy) vs mutengesi (literally: (some)one who is selling; figuratively: (some)one who is selling out)

(c) -bika (cook) vs -bikwa (be cooked) vs -bikisa (literally: cause someone to cook; figuratively: acquire/come into the possession of an own household as a newly married woman)

Derivation is commonly referred to as a process of word formation by which new lexical items are created (see, for example, Bolinger 1968 and Katamba 1993). If such a definition of derivation is maintained, then both mufambi and mutengesi are forms of different lexemes (derived from the verbs -famba and -tenga respectively) and should both be listed in the dictionary as distinct entries, each with its own definition. However, a look at Chimhundu's (2001) Shona dictionary, for example, shows that whilst the noun mufambi was excluded, mutengesi was included. The question one would ask is "Why?", since the two look quite similar in form and in their manner of derivation; both are nouns derived from verb bases by a similar process of nominalisation. We can only infer that mufambi was omitted because its meaning can easily be traced from that of the verb -famba, from which it is derived. On the other hand, mutengesi was included because, in addition to the easily predictable sense of "(some)one who is selling", the process of nominalisation has also introduced a figurative sense, which cannot be deduced from the way the noun is derived from the verb. The same can be said of the extended verbs -bikwa and -bikisa where -bikwa is excluded from the dictionary and -bikisa is included. As we will argue later when we look at lexical meaning, such reasoning and decisions are informed by insights from theoretical research in cognitive linguistics dealing with derivations of various kinds.

\section{Tone Marking}

The correct pronunciation of words is one reason why the speakers of a language consult dictionaries. To show the importance of tone marking, let us look at the following entries from Chimhundu (1996). 
(3) (a) guru K- z 5. Guru imhuri yomurume mumwe chete, inenge ine vakadzi vakawanda navana vazhinjiwo. (Guru is a family owned by one man, who has many wives and many children.)

(b) guru D- z 5. Iri zimwena rinoita pachuru, rakakura, munogara nyoka kana zvimwewo zvikara zvesango. (This is a big hole usually on an anthill, where snakes and other dangerous wild animals can reside.)

(c) guru DK z 5. Guru inhengo yedumbu remhuka, munogaiwa chikafu chose chinenge chadyiwa, rakafanana nematauro okugezesa mukati maro. (Guru is a part of an animal's stomach, where food is digested and whose inside looks like a bathing towel.)

Although these three words are spelt the same, they refer to different things solely because they are pronounced differently. For this reason all of them are listed in the dictionary as different entries.

Tone marking is a historical problem in African lexicography. In fact, the general history of phonological studies has undergone many changes, with phonologists proposing different ways of the phonological representation of sounds in dictionaries. Because of the confusion surrounding this area of lexicographic description, in most traditional dictionaries of African languages tone marking occurred in a haphazard manner, with most dictionary compilers not even knowing where and how this should be done. Even in some recent dictionaries (see, for example, TUKI 2000, Hadebe 2001, Nkomo and Moyo 2006, and Mbatha 2006), tone marking was actually omitted for fear of mishandling it. However, the insights of phonological theories, particularly Goldsmith's Autosegmental Phonological Theory, have shown that unlike languages having an abundance of contour tones, in African tone languages the primary opposition is between level tones. It is research in phonological theory by Goldsmith and others that has established that many African languages have two level tones only, high and low, which is marked at syllable level. In fact, it is research on phonological theory that made it possible for tone to be marked with some measure of consistency in some dictionaries of African languages (see, for example, Dale 1981 and Chimhundu 1996, 2001, among others, where tone is actually contrasted and marked as either high or low on each syllable). It is also research in phonological theory that has shown that words that differ only in tone are as distinct from each other as words with different vowels, hence the need to treat them as distinct in dictionaries. Furthermore it is phonological theory that has provided the notation allowing African lexicographers to mark tone in their dictionaries.

\section{Grammatical Categorisation}

We have already intimated in the introductory section that one of the lexicographer's chief tasks is to deal with grammatical categorisation and labelling of lexical items, that is, placing words or parts of words into word classes tradi- 
tionally identified, among others, as verb, noun, pronoun, ideophone or adjective. In other words, the lexicographer has to show the characteristic syntactic functions of words selected for inclusion in the dictionary. For example, if a word is a noun, information about its class membership as well as its singular/plural categorisation would be provided. If it is a verb, information about its transitivity would be presented. However, the provision of grammatical information about words is sometimes a big challenge to lexicographers, especially those without proper linguistic training. Experience in the process of compiling dictionaries has shown that word class categorisation is difficult to state explicitly in some cases. Faced with a situation where they could not classify some words, the editors of Chimhundu (1996) eventually created a kanu (interjective) category to which all the words causing categorisation problems were assigned. They agreed that further research was needed on the relevant words. However, a look at a theory like Lexical Functional Grammar (LFG) shows that linguistic theory has much to offer in trying to solve problems similar to this one. Since it deals with the lexical representation of words, LFG helps in shedding light on such issues as word class categorisation as well as the morphosyntactic characteristics of lexical items. To illustrate the different kinds of information to which we are referring here, let us look at the LFG representation of the following Shona sentence.

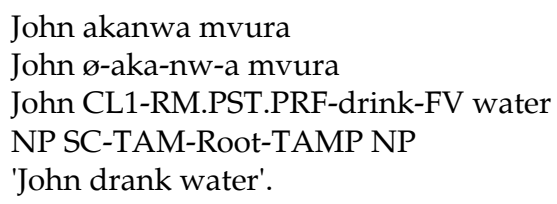

In this sentence, there are three lexical entries, that is, (a) John, (b) akanwa and (c) mvura, which can be analysed using LFG principles as follows:

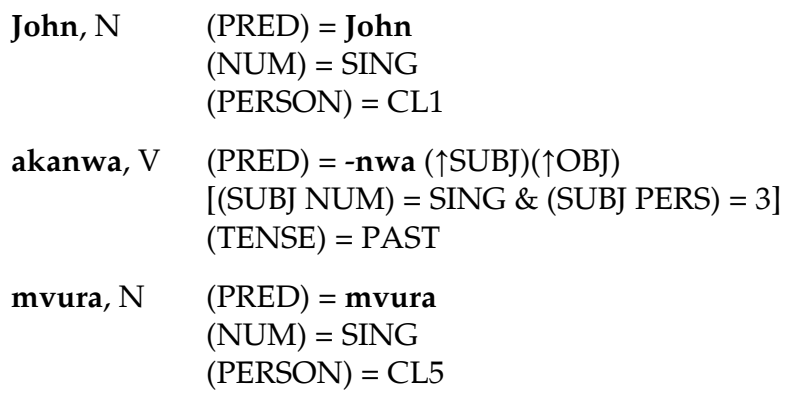

This analysis shows that much useful lexicographic information is revealed. For example, we notice from its representation that akanwa belongs to the verbal category. We also notice that the verb, -nwa, requires two semantic arguments which are associated with two grammatical functions, that is, 'subject' and 'object', making it a transitive verb. Transitivity, as we have already suggested, is one aspect that is usually indicated for all verbs in most dictionaries. 
Let us consider how this verb is treated in Chimhundu (1996).

$$
\text { -nwa K it. Kunwa kumedza chinhu chakaita sedoro, mvura kana tii. (Kunwa is }
$$
to swallow something like beer, water or tea.)

In the above example, it., an abbreviation of itika, shows that -nwa is a transitive verb that takes a subject and an object in a sentence. Therefore, the theoretical principles that guide lexicalist frameworks such as LFG and the analyses that result from the application of these principles should be very useful in providing relevant lexicographic information.

\section{Lexical Meaning}

Although it has become the norm in modern lexicography also to include information about, for example, the spelling, pronunciation and etymology of words in dictionaries, Béjoint (2000: 6) notes that the main objective of dictionaries is to define words and terms. In other words, the most central aspect is word meaning, especially in monolingual dictionaries. In his description of monolingual dictionaries, Landau (2001: 8-9) says:

A monolingual dictionary [...] provides many kinds of information about its entry words but most importantly gives definitions [...]. The chief purpose of a monolingual dictionary is to explain, in words likely to be understood, what other words mean.

The importance attached to word meaning in monolingual dictionaries means that the defining task should be taken seriously. However, as again noted in Zgusta (1971), Hartmann (1983), Good (1988), Jackson (1988), Svensén (1993) and Landau (2001), among others, the description of word meaning is one of the most difficult tasks lexicographers must perform. In providing the designative and connotative meanings of words, lexicographers are usually faced with many difficult choices. For example, they have to answer the following basic questions, which should help them to create definitions that are precise, comprehensive, exhaustive and all-inclusive and that are also given in both a linguistic and cultural context: (a) Should the focus be on the senses of individual words?, (b) Which readings of a word should be considered relevant?, (c) Which type(s) of meaning should be defined?, (d) Which linguistic perspective(s) should be taken?, and (e) Which defining format(s) should be used? In answering these questions, lexicographers have many other variables to consider. For example, they have to think about their audience and the purpose of the dictionary. In handling all these, lexicographers cannot solely depend on their intuition; instead, they have to rely on research results from other fields. Good (1988) argues that in order to understand this complex situation and to make informed decisions and choices, but at the same time to avoid being too casual in the way they display the various senses they attribute to a word, lexi- 
cographers can benefit from insights from the linguistic or philosophical debate on the semantic structure of words. Linguistic theories regarding semantics or meaning as the centre of grammatical description such as those of the conceptualist or cognitive tradition ${ }^{\dagger}$ (for example, Cognitive Grammar, Construction Grammar and Frame Semantics) can be exploited in supporting lexicographic decisions. Central to the conceptualist approach to meaning is the assumption that meaning is a cognitive phenomenon and thus it should be analysed as such. Following this assumption, the description of lexical meaning should, therefore, be understood with reference to a structured background of experience, beliefs or practices constituting a kind of conceptual prerequisite for understanding meaning (Fillmore and Atkins 1992: 76). Linked to this is also the hypothesis that knowledge of language emerges from language use, that is, that semantic structure is built up from cognition of specific utterances on specific occasions of use. Viewed this way, the assumption in the conceptualist approach is that word concepts may not be understood apart from the social and cultural institutions in which the action, state or thing is situated. Instead, the view is that to fully capture the meanings of words, both the language and the socio-cultural context in which they are used has to be understood. Thus, obtaining insights from the principles guiding the treatment of meaning in Cognitive Grammar, for example, lexicographers should be able to create definitions fulfilling one aspect of the meanings desired in dictionaries, especially monolingual dictionaries: socio-cultural relevance. Because meaning is too broad a concept, let us look at a few challenging aspects of it, and try to show how linguistic theory has helped or should help lexicographers.

Let us start with the treatment of polysemy, one of the lasting challenges in the provision of meaning in monolingual dictionaries. Polysemy is commonly described as a situation where a word is associated with two or more distinct but related senses. Faced with a word with multiple senses, lexicographers' first challenge is to decide which meaning or meanings to include in or exclude from the dictionary. Depending on the intended audience and the purpose of the dictionary, lexicographers may focus on the most common sense(s) only, or may include less common ones as well. They may restrict their defining efforts to general senses or may include marked readings of the words as well. Having selected the senses to include in the dictionary, lexicographers have to face the next challenge, that of sense ordering in cases where more than one sense has been selected. Generally speaking, haphazard and ad hoc decisions regarding sense ordering are found in most dictionaries of African languages. However, as noted in Inglis (2003), the principles guiding the Prototype Theory can contribute much to solving problems linked to polysemy by ensuring consistency in dealing with issues such as sense ordering. The Prototype Theory makes a crucial distinction between central and peripheral senses of a word and provides guidelines for determining the core-periphery distinction. The study of verbs using the Prototype Theory (see, for example, Chabata 2007) has shown that in each polysemous situation, there is a fairly specific 
central sense of a word, which should be regarded as its prototypical or core sense. The other separate but related sense(s) become(s) the word's less typical sense(s). Whilst prototypical senses are classified as those that designate aspects basic to human experience, hence typical of the way we use language to express our conceptualisation of the physical world, the peripheral senses are those whose interpretation depends on similar or related elements of the more basic senses. Such principles of classifying word meanings, if followed, make it easier for the lexicographer in determining the core sense(s) of words, which should logically be listed first and also the peripheral sense(s) that should be listed later or last. To illustrate what is meant, let us compare the ordering of the meanings provided for the verb -minyura in Chimhundu 1996 and Chimhundu 2001, respectively:

(6) (a) -minyura D it. 1 Kuminyura kutaura zvinhu zvisinganzwikwi, kana zvine svoto kune vakateerera. (Kuminyura is to talk in an inaudible manner, or in a way that provokes those who are listening.) 2 Kuminyura magodo kuapesanisa kana kuasvodogora panzvimbo paanosangana, sezvakaita pagokora kana pachitsitsinho. (Kuminyura is to dislocate bones at the places where they meet, such as at the elbow or the toes.)

(b) -minyura D it. 1 Kuminyura magodo kuapesanisa kana kuasvodogora panzvimbo paanosangana, sezvakaita pagokora kana pachitsitsinho. 2 Kuminyura kutaura zvinhu zvisinganzwikwi, kana zvine svoto kune vakateerera.

A look at this entry shows that it is provided with exactly the same definitions in both dictionaries. The only difference lies in the ordering of the senses, which is reversed. The obvious question one is tempted to ask is "Why?" In trying to understand the reason for this, we should note that in the example from the 2001 dictionary, the sense ordering follows what we have noted as the principles guiding the ordering of multiple senses using the Prototype Theory. One could conclude that the editors of the later dictionary were influenced by insights from the Prototype Theory to meaning, hence the decision to re-order the definitions.

Another challenge concerns the meanings of complex structures such as complex nominal constructions and extended verbs that we have already touched upon in our discussion of headword selection. A look at some dictionaries published in certain African languages (see, for example, Moreno 1988 for Nambya; Chimhundu 1996, 2001 for Shona; Hadebe 2001 for Ndebele; and Mbatha 2006 for Zulu) shows that the meanings of complex structures are generally treated as predictable from their respective constructional patterns. In fact, it is because of this general treatment that most complex structures are excluded from these dictionaries. The assumption is that it should be fairly easy for dictionary users who want to know the meanings of complex structures to simply add up the meanings of their component parts. With regard to extended verbs, for example, the assumption is that it is easy to deduce the meanings of these verbs by the addition of the meanings of parts of the ex- 
tended form, that is, the meanings of the verb base and the verbal extension. This explains why the majority of extended verbs and their senses were excluded from the above-mentioned dictionaries. However, the study of the causatively extended verbs in Nambya (see, for example, Chabata 2007), and the application of the principles guiding Cognitive Grammar in its treatment of the meanings of complex structures, have shown that verbal extensions add meanings to verb bases, which are more specialised than is usually assumed, and some of these meanings are not analysable from the sum total of the meanings of parts of the extended verb. More often than not, the meanings of extended verb forms cease to be compositional as is implied in the various treatments that extended verbs have received in most existing dictionaries of African languages. Instead, it was discovered that extended verbs normally have both compositional and non-compositional meanings. It was further discovered that the non-compositional meanings are a result of semantic extension through processes such as metaphor, metonymy and specialisation. Such theoretical insights should be useful when dealing with headword and sense selection; that is, if the meaning of an extended verb is predictable from its constructional pattern, then it should be excluded from the dictionary, and if the meaning is unpredictable or idiosyncratic, then it should be included in the dictionary. To illustrate this, let us take an example of one Nambya extended verb, -lyisa, which is derived by the addition of the causative extension -is- to the verb root, -ly- (eat). The sum total of the meanings of -ly- and -is- would give us the meaning, 'cause to eat; feed'. However, -lyisa has two other senses, that is, (a) 'brainwash' and (b) 'poison', which are not analysable from the meanings of parts of the verb. Whilst meaning (a) is a metaphorical extension from the basic sense of causing someone to eat something, meaning (b) is a form of specialisation. From a Cognitive Grammatical point of view, therefore, the creation or derivation of complex structures such as extended verbs is not a mere mathematical process of addition but a process yielding both predictable and unpredictable meanings. The principles of Cognitive Grammar are thus informative in understanding the different kinds of meaning of complex structures. Insights from Cognitive Grammar regarding the predictable/unpredictable distinction, therefore, should help lexicographers to decide which senses to include in or omit from a dictionary. In this case, predictable senses can be omitted, for they are mathematically derivable, but unpredictable senses may need to be included since they may not be recoverable by any other means.

\section{Conclusion}

In this article, we have tried to show that theoretically guided investigations into linguistic structure are useful to the lexicographer of African languages. Taking our examples mostly from Shona, we have also tried to show that every aspect of a dictionary entry benefits in some way from research in theoretical 
linguistics. This does not however mean that African lexicographers, whom we have also identified as trained linguists, ask themselves continually when constructing entries which linguistic theory would be useful for handling a specific aspect. Instead, linguistic theory is part and parcel of their lexicographic equipment. All in all, we maintain that knowingly or unknowingly, consciously or unconsciously, lexicographers, not only of African languages but of all languages, benefit from insights derived from theoretical linguistic research. In fact, we believe that data from linguistic theories is relevant to dictionary making in any language, African or otherwise. Although this article mainly focused on the relevance of linguistic data to lexicography, we should note that the links between the two fields of study are often mutual. For example, as we have already tried to show, whilst lexicographers depend on data from linguistic research in almost all the stages of compiling dictionaries, linguists in turn utilise lexicographic information in answering many linguistic questions, for example checking such factors as, among many others, the evidence of the meaning range and the origin and semantic change of lexical items.

\section{Note}

$\dagger \quad$ For a fuller discussion of how meaning is viewed from a conceptualist or cognitive linguistic approach, refer to Fillmore (1982), Langacker (1987, 2000), Svorou (1994), Goldberg (1995, 2006), Ungerer and Schmid (1996), Sweetser (1999), Kövecses (2002) and Taylor (2002, 2003), among many others.

\section{References}

Béjoint, H. 1994. Tradition and Innovation in Modern English Dictionaries. Oxford: Clarendon Press. Béjoint, H. 2000. Modern Lexicography: An Introduction. New York: Oxford University Press.

Bolinger, D.L. 1968. Entailment and the Meaning of Structures. Glossa 2: 119-127.

Chabata, E. 2007. The Nambya Verb with Special Emphasis on the Causative. Unpublished Ph.D. Thesis. Oslo: University of Oslo, Department of Linguistics and Scandinavian Studies.

Chimhundu, H. (Ed.). 1996. Duramazwi reChiShona. Harare: College Press.

Chimhundu, H. (Ed.). 2001. Duramazwi Guru reChiShona. Harare: College Press.

Dale, D. 1981. Duramazwi: A Shona-English Dictionary. Gweru: Mambo Press.

Fillmore, C.J. 1982. Frame Semantics. The Linguistic Society of Korea (Ed.). 1982. Linguistics in the Morning Calm: 111-157. Seoul: Hanshin.

Fillmore, C.J. and B.T. Atkins. 1992. Toward a Frame-based Lexicon: The Semantics of RISK and its Neighbors. Lehrer, A. and E.F. Kittay (Eds.). 1992. Frames, Fields and Contrasts: New Essays in Semantic and Lexical Organisation: 75-102. London/Hillsdale: Lawrence Erlbaum Associates.

Geeraerts, D. 1987. Types of Semantic Information in Dictionaries. Ilson, R. (Ed.). 1987. A Spectrum of Lexicography: Papers from AILA, Brussels 1984: 1-10. Amsterdam: John Benjamins.

Goldberg, A.E. 1995. Constructions: A Construction Grammar Approach to Argument Structure. Chicago/London: The University of Chicago Press. 
Goldberg, A.E. 2006. Constructions at Work: The Nature of Generalization in Language. Oxford: Oxford University Press.

Goldsmith, J.A. 1976. Autosegmental Phonology. Unpublished Ph.D. Thesis. Boston: Massachusetts Institute of Technology, Thesis Department of Foreign Literatures and Linguistics.

Good, C. 1988. Lexicography and Linguistic Theory; with Special Reference to German. New German Studies 15(2): 81-110.

Gouws, R.H. and D.J. Prinsloo. 2005. Principles and Practice of South African Lexicography. Stellenbosch: SUN PReSS.

Hadebe, S. et al. (Eds.). 2001. Isichazamazwi SesiNdebele. Harare: College Press.

Hartmann, R.R.K. 1983. On Theory and Practice: Theory and Practice in Dictionary-making. Hartmann, R.R.K. (Ed.). 1983. Lexicography: Principles and Practice: 3-11. London: Academic Press.

Hyman, L.M. 2006. African Languages and Phonological Theory. Berkeley: University of California. http://www.linguistics.berkeley.edu/ hyman/GLOT_Phonology_African_Lgs.pdf

Inglis, D. 2003. Cognitive Grammar and Lexicography. Payap University Graduate School.

Jackson, H. 1988. Words and their Meaning. London/New York: Longman.

Katamba, F. 1993. Morphology. London: The Macmillan Press.

Kövecses, Z. 2002. Metaphor: A Practical Introduction. Oxford/New York: Oxford University Press.

Landau, S.I. 2001. Dictionaries: The Art and Craft of Lexicography. Second Edition. Cambridge: Cambridge University Press.

Langacker, R.W. 1987. Foundations of Cognitive Grammar. Volume 1: Theoretical Prerequisites. Stanford: Stanford University Press.

Langacker, R.W. 2000. Grammar and Conceptualization. Berlin/New York: Mouton de Gruyter.

Mbatha, M.O. (Ed.). 2006. Isichazamazwi sesiZulu. Pietermaritzburg: New Dawn Publishers.

Moreno, A. 1988. Nambya Dictionary. Gweru: Mambo Press.

Nkomo, D. and N. Moyo (Eds.). 2006. Isichazamazwi SezoMculo. Gweru: Mambo Press.

Svensén, B. 1993. Practical Lexicography: Principles and Methods of Dictionary-Making. Oxford/New York: Oxford University Press.

Svorou, S. 1994. The Grammar of Space. Amsterdam/Philadelphia: John Benjamins.

Sweetser, E. 1999. Compositionality and Blending: Semantic Composition in a Cognitive Realistic Framework. Janssen, T. and G. Redeker (Eds.). 1999. Cognitive Linguistics: Foundations, Scope, and Methodology: 129-162. Berlin: Mouton de Gruyter.

Taylor, J.R. 2002. Cognitive Grammar. Oxford: Oxford University Press.

Taylor, J.R. 2003. Linguistic Categorization. Third Edition. Oxford: Oxford University Press.

TUKI. 2000. English-Swahili Dictionary. Second Edition. Dar es Salaam: Institute of KiSwahili Research.

Ungerer, F. and H. Schmid. 1996. An Introduction to Cognitive Linguistics. London/New York: Longman.

Urdang, L. 1963. Review of Problems in Lexicography. Language 39: 586-594.

Yong, H. and J. Peng. 2007. Bilingual Lexicography from a Communicative Perspective. Amsterdam/ Philadelphia: John Benjamins.

Zgusta, L. 1971. Manual of Lexicography. The Hague: Mouton. 